\title{
Red River
}

\section{Melissa Gordon}

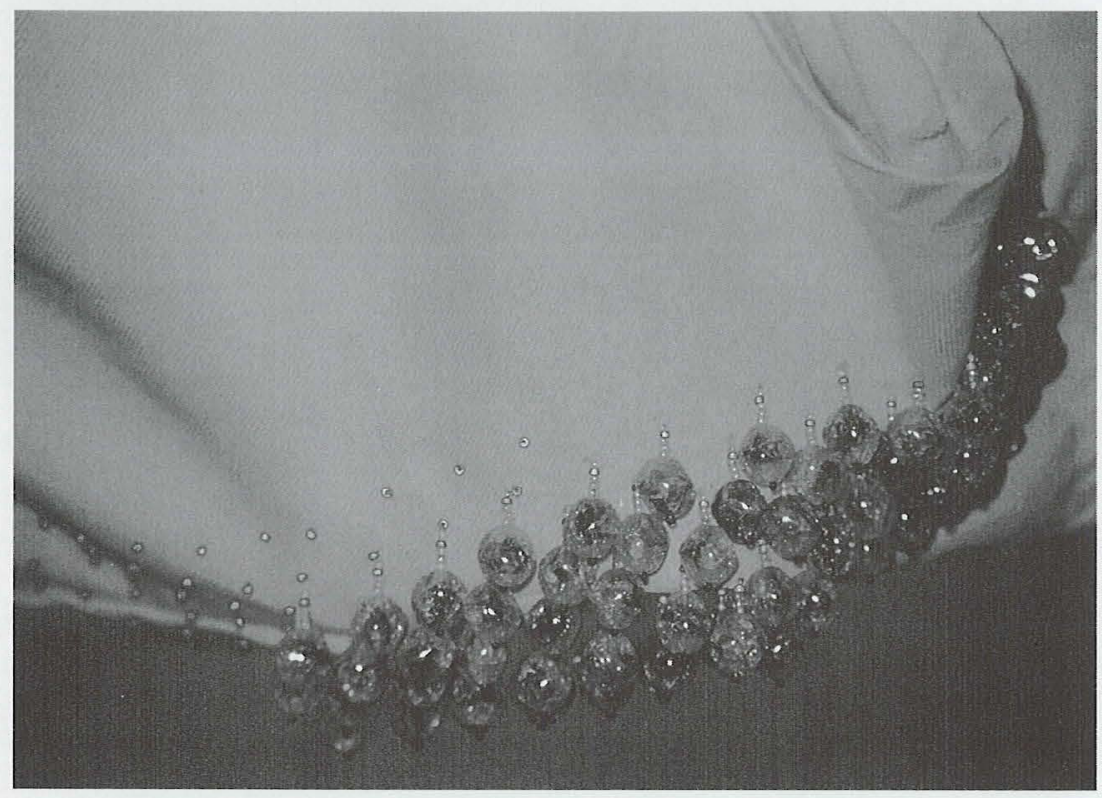

2001, detail, altered garment, glass beads 
Red River · 83

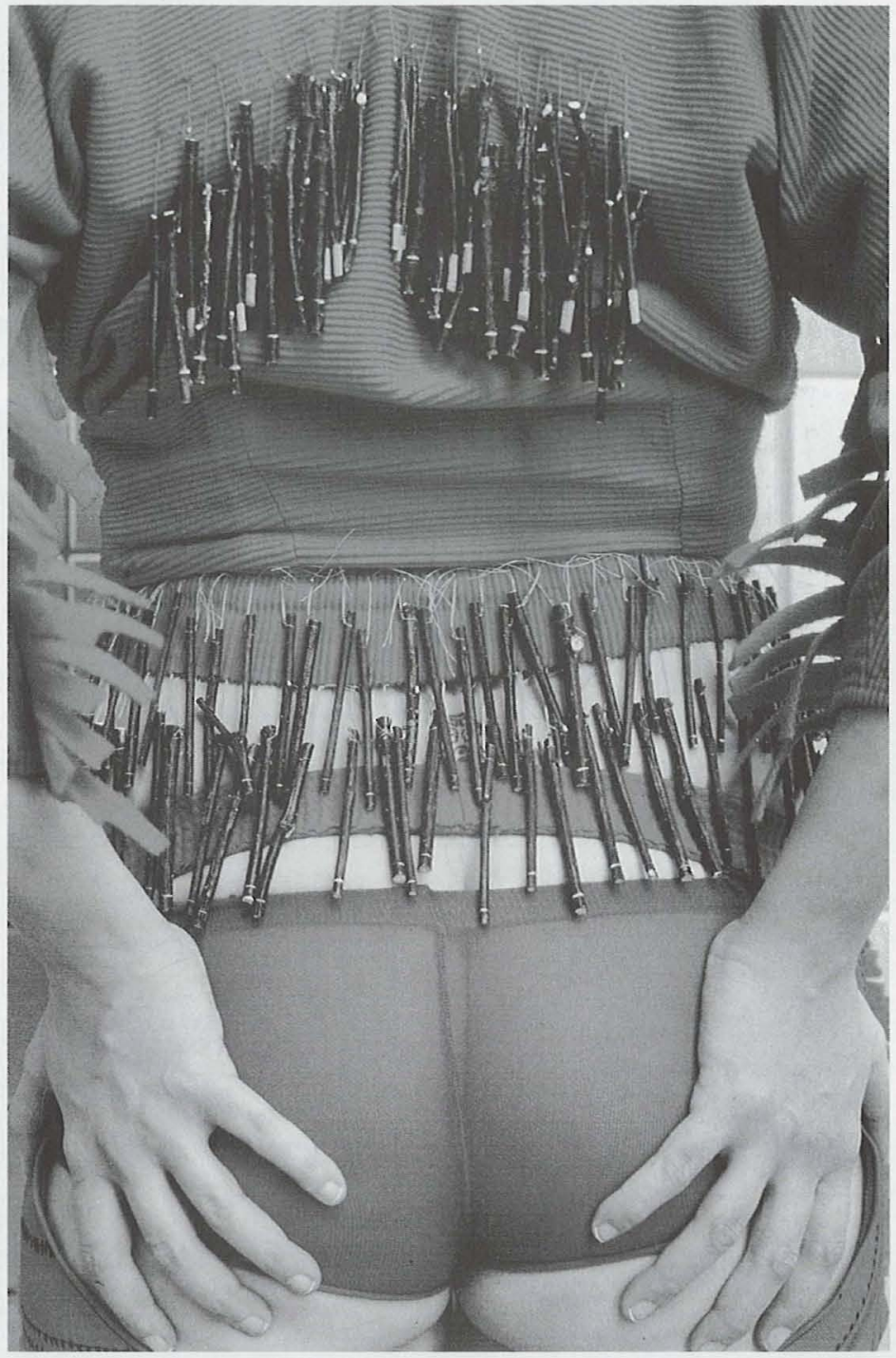

2001, detail, altered garment, wooden beads 